\title{
(Dis)Trust your gut: the gut microbiome in age-related inflammation, health, and disease
}

\author{
Thomas W. Buford
}

\begin{abstract}
Chronic inflammation represents one of the most consistent biologic features of aging. However, the precise etiology of persistent low-grade increases in inflammation remains unclear. Recent evidence suggests that the gut microbiome may play a key role in age-related inflammation. Indeed, several studies have indicated that older adults display an altered composition of the gut microbiota, and early evidence indicates that this dysbiosis is associated with the presence of several key circulating inflammatory analytes. The present review summarizes knowledge on age-related inflammation and discusses how potential relationships with gut dysbiosis may lead to novel treatment strategies in the future.

"The pattern of disease is an expression of the response of man to his total environment (physical, biological, and social); this response is, therefore, determined by anything that affects man himself or his environment." - Rene Dubos, 1961
\end{abstract}

\section{Background}

In humans, aging is a continual and progressive process that results in decreased physiologic function across all organ systems [1]. These physiologic decrements result in an increased vulnerability to infection and disease that dramatically elevates mortality risk [2, 3]. Compared to persons 25-44 years of age, mortality risk among older adults is elevated by 100 -fold for stroke and chronic lung disease, roughly 90 -fold for heart disease, pneumonia, and influenza, and over 40-fold for cancer [2]. Given the rapid increase in life expectancy and increasing proportion of older adults within the population [4], an increased understanding of the biologic mechanisms which underlie age-related increases in disease prevalence are warranted.

\section{Aging and inflammation}

Though the etiologies of age-related diseases are quite diverse, significant evidence implicates chronic, lowgrade inflammation as one of the most consistent biologic features of both chronological aging and various

\section{Correspondence: twbuford@uab.edu}

Department of Medicine, University of Alabama at Birmingham, 933 19th Street South, Birmingham, AL 35294, USA age-related diseases/disorders [5-8]. In fact, a recent PubMed search for the terms "aging and inflammation" revealed nearly 10000 publications in this area (Fig. 1) with this pair of risk factors implicated in the pathobiology of a wide variety of diseases and disorders across nearly every organ system (Fig. 2a).

Inflammation is commonly recognized as a localized response to tissue injury or infection that aids in the repair of damaged tissue and/or destruction of the harmful agent [4]. Classically characterized by pain, heat, redness, swelling, and loss of function, acute inflammation is typically resolved (in healthy individuals) in relatively short order to promote the restoration of tissue function. However, during advanced age, the ability to resolve inflammation becomes impaired leading to sustained tissue infiltration of leukocytes and the chronic release of pro-inflammatory cytokines and chemokines [9]. As a result, the initial local event has long-term systemic consequences.

Indeed, elevations in pro-inflammatory mediators such as interleukin-6 (IL-6), C-reactive protein (CRP), and tumor necrosis factor alpha (TNF- $\alpha$ ) have been consistently reported during late adulthood even in the absence of acute infection [10-12]. Though it is unknown if these 


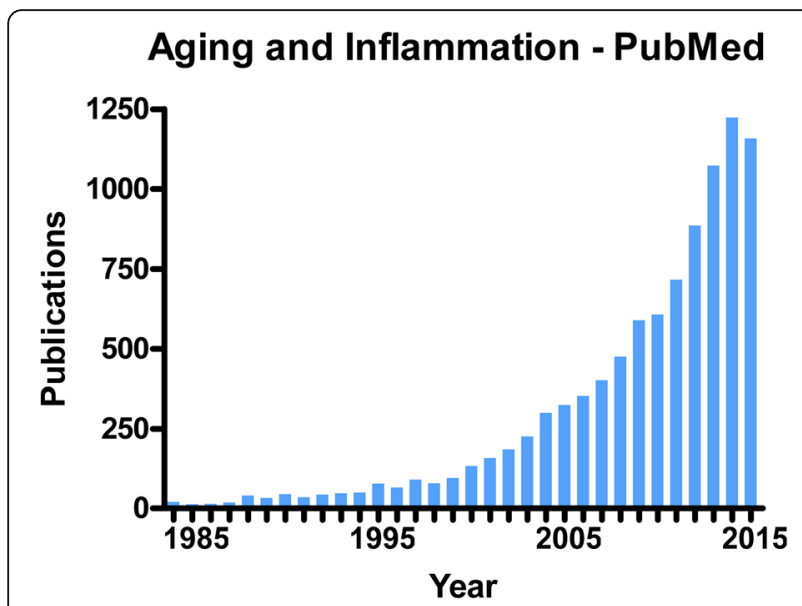

Fig. 1 Number of PubMed citations by year using the search term "aging and inflammation"

inflammatory mediators directly cause adverse health outcomes, chronic low-grade inflammation has been associated with the prevalence of a wide-range of age-related comorbidities-cardiovascular disease [13-15], insulin resistance and diabetes [16-18], osteoporosis [19-21], cognitive decline and dementia [22-24], frailty and disability [25-27], and cancer [28-30]-as well as mortality [31-33].

Though factors such as obesity and insulin resistance, smoking, and changes in circulating sex hormone concentrations have been associated with age-related inflammation [34], the largest contributor to increases in inflammatory mediators has traditionally been thought to decrease in the efficiency of the immune system, i.e., immuno-senescence $[6,8]$. Immuno-senescence is characterized by thymus atrophy, reductions in neutrophil function, naïve $\mathrm{T}$ cell number, and the cytotoxic capacity of natural killer cells, and lowered B-cell antibody production in response to antigen $[35,36]$. The most widely held belief regarding the cause of immunesenescence is that chronic lifetime antigenic burden exhausts a finite capacity of the organism's immune system [4, 37, 38]. Therefore, we exchange protection against infection for long-term risks of chronic inflammation and disease $[4,39]$.

Very recently, however, emerging evidence has suggested that the gut microbiome may play an integral role in these age-related inflammatory changes. Recent evidence indicates that advanced age is associated with changes in microbiota composition characterized by a loss of diversity in the core taxa [40]. Moreover, these age-related changes in the microbiome have also been recently associated with key geriatric syndromes including physical frailty [41] and dementia [42]. Therefore, the objective of this review is to discuss the available evidence related to gut microbiome and aging, with particular emphasis on age-related inflammation and associated diseases/conditions.

\section{The gut microbiome and health}

The human intestinal tract (i.e., "gut") is inhabited by over 100 trillion microorganisms; including over 1000

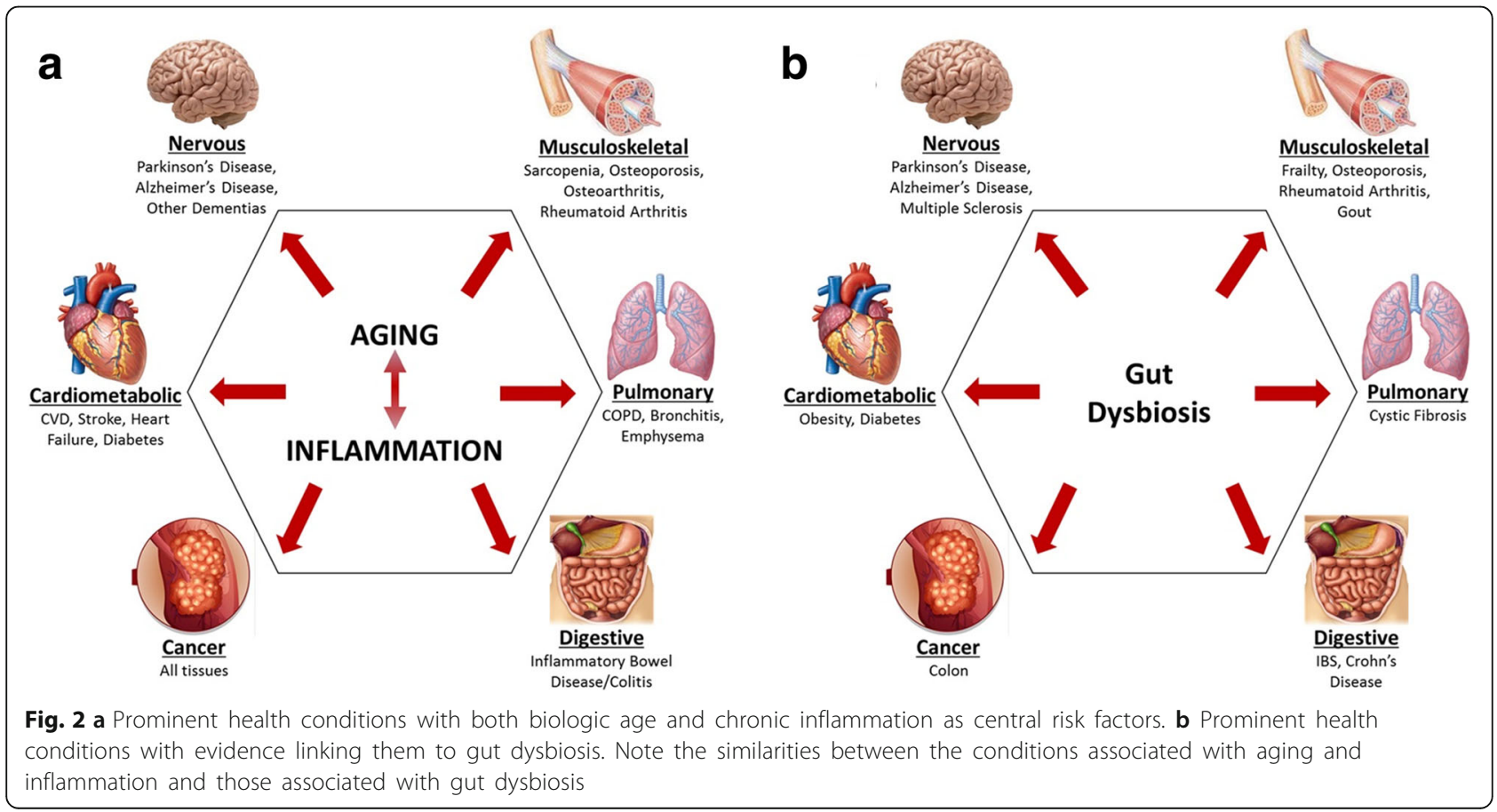


species of known bacteria.[43] These organisms have coevolved with humans over millennia to live together for mutual benefit $[44,45]$. Though commonly overlooked in considerations of human health and disease treatment (hence the nickname the "forgotten organ" [46]), gut microorganisms encode $>150$ times more genes than the human genome and are highly involved in numerous metabolic reactions which influence normal host physiology and metabolism [47, 48]. In fact, an enormous portion of the body's constitutive immune function is dedicated to maintaining homeostasis with the microbiota, as evidenced by the fact that $70 \%$ of the body's lymphocytes reside in the gut-associated lymphoid tissue [49].

Given the substantial portion of the immune system dedicated to maintaining host relationship with the microbiome, it is perhaps unsurprising that gut microbiota are heavily involved in local inflammatory responses to acute injury and/or infection. Indeed, commensal bacteria are a critical regulator of regulatory immune responses including tolerance-the active suppression of inflammatory responses to food and other orally ingested antigens [50]. In fact, these bacteria are known to play a protective role in acute inflammatory responses to injury at least in part through toll-like receptor (TLR) activation to promote tissue repair and survival [51]. Moreover, immune cells also regulate inflammation in intestinal injury and allergy via recognition of short-chain fatty acids (SCFA) produced via bacterial breakdown of indigestible dietary components such as fiber [52].

Failure to regulate these responses is wellestablished as a contributor to the development of food allergies and/or various inflammatory bowel diseases affecting the gut. More recently, however, it has become apparent that changes to microbial composition and density can alter immunity and inflammation within organs distal from the intestine [53]. For example, the reduction of beneficial gut bacteria via antibiotic treatment has demonstrated impaired systemic allergic inflammatory responses as well as immune responses to viral (influenza) infections [54-56]. Though beyond the scope of the current review, I refer readers to an excellent review by Belkaid and Hand [50] for in-depth discussion of the potential mechanisms underlying microbiota-based changes to systemic immunity and inflammation.

In line with known interactions of the microbiome with the systemic circulation and distal tissues, gut dysbiosis-commonly defined as a disturbance of or change in the density and/or composition of gut microbiota - has been linked to a wide variety of diseases and health conditions (Fig. 2b). These conditions include cystic fibrosis [57], inflammatory bowel conditions (irritable bowel syndrome, Crohn's disease, and colon cancer [58-60], neurological diseases (Parkinson's disease, Alzheimer's disease, and multiple sclerosis)) [61-63], metabolic diseases (obesity and diabetes) [64, 65], as well as musculoskeletal conditions (frailty, osteoporosis, rheumatoid arthritis, and gout) [41, 66-68]. Notably, as evidenced by the remarkable similarity between Fig. 2a, b, the majority of these conditions exhibit age-related increases in incidence. Accordingly, it seems relevant to explore the possibility that age-related inflammation may stem at least partially from changes to the gut microbiome.

\section{The aging gut microbiome}

As noted above, the human ageing process is associated with gradual declines in function across virtually every bodily organ. In contrast, however, the bacterial organisms in the gut do not age per se and thus might be unexpected to follow the typical trajectory of physiological decline seen elsewhere in the body [69]. And yet, as pointed out by O'Toole and Jeffery [69], older individuals often experience gut-associated comorbidities, changes in diet and physical activity patterns, and other gut-related physiologic changes which may influence gut bacteria. Thus, questions persist regarding how such changes may interact with gut bacteria to influence microbiome composition and function.

Compared to evidence related to aging and inflammation, less is known regarding associations between aging and the microbiome. In fact, in contrast to the thousands of peer-reviewed publications on aging and inflammation, a PubMed search for "aging and microbiome" yielded only 466 results and a search for "aging and dysbiosis" yielded a mere 34. Moreover, only a handful of studies to date have investigated the aging microbiome in humans (Table 1). Still, at least two early studies in this area have documented that advanced age is associated with changes to both the composition and stability of gut microbiota [40, 70]. Biagi et al. reported that a group of centenarian from Northern Italy displayed low species diversity compared to younger adults ( $\sim 30$ years of age). They also noted specific changes within Firmicutes (one of the two dominant phyla commonly found in the gut) subgroups and enrichment of Proteobacteria-a group containing many opportunistic bacteria which can overtake commensal bacteria and induce pathology [70]. These microbiome changes were also characterized by a loss of genes for short-chain fatty acid production and an overall decrease in the saccharolytic potential, while proteolytic functions were more abundant than in the intestinal metagenome of younger adults [71]. Interestingly, these changes in bacterial 
Table 1 Studies investigating aging and the gut microbiome humans

\begin{tabular}{|c|c|c|c|c|c|c|}
\hline Study & $N$ & Population & Age & Age-affected microbiota & Age effect & Additional details \\
\hline $\begin{array}{l}\text { Hopkins et al. } \\
\text { (2002) [130] }\end{array}$ & 15 & British & $\begin{array}{l}21-34 \text { years } \\
67-88 \text { years } \\
67-73 \text { years CDAD }\end{array}$ & $\begin{array}{l}\text { Bacteroides species diversity } \\
\text { Bifidobacteria species diversity }\end{array}$ & $\uparrow$ & $\begin{array}{l}\text { CDAD patients had greater diversity } \\
\text { lactobacilli/clostridia but reducted } \\
\text { bacteriodes, prevotella, and bifidobacteria }\end{array}$ \\
\hline $\begin{array}{l}\text { Hayashi et al. } \\
\text { (2003) [131] }\end{array}$ & 6 & Japanese & $79-84$ years $^{a}$ & $\begin{array}{l}\text { Clostridium rRNA subcluster XIVa } \\
\text { Bifidobacteria \# } \\
\text { Ruminoccoccus obeum }\end{array}$ & $\downarrow$ & \\
\hline $\begin{array}{l}\text { Woodmansey et al. } \\
\text { (2004) [132] }\end{array}$ & 28 & British & $\begin{array}{l}19-35 \text { years } \\
67-75 \text { years } \\
73-101 \text { years HE }\end{array}$ & $\begin{array}{l}\text { Bacterioides } \\
\text { Bifidobacteria (no. and diversity) }\end{array}$ & $\downarrow$ & $\begin{array}{l}\text { Hospitalized patients displayed age- } \\
\text { related changes along with increased } \\
\text { proteolytic bacteria no. and diversity }\end{array}$ \\
\hline $\begin{array}{l}\text { Van Tongeren et al. } \\
\text { (2005) [74] }\end{array}$ & 23 & Dutch & 70-100 years & N/A & N/A & $\begin{array}{l}\text { High frailty scores associated with } \\
\text { reduced lactobacilli, bacteroides, } \\
\text { prevotella no.; increased enterobacteria }\end{array}$ \\
\hline $\begin{array}{l}\text { Biagi et al. } \\
(2010)[70]\end{array}$ & 84 & Italian & $\begin{array}{l}25-40 \text { years } \\
59-78 \text { years } \\
99-104 \text { years }\end{array}$ & $\begin{array}{l}\text { Clostridium cluster XIVa } \\
\text { Bacilli } \\
\text { Proteobacteria }\end{array}$ & $\begin{array}{l}\downarrow \\
\uparrow \\
\uparrow\end{array}$ & $\begin{array}{l}\text { Young and elderly showed similar } \\
\text { microbiota, while differences observed } \\
\text { in centenarians only. }\end{array}$ \\
\hline $\begin{array}{l}\text { Claesson et al. } \\
\text { (2011) [72] }\end{array}$ & 170 & Irish & $\begin{array}{l}28-46 \text { years } \\
>65 \text { years }\end{array}$ & $\begin{array}{l}\text { Firmicutes } \\
\text { Clostridium cluster IV } \\
\text { Ruminococcaceae }\end{array}$ & $\begin{array}{l}\downarrow \\
\uparrow \\
\uparrow\end{array}$ & \\
\hline $\begin{array}{l}\text { Claesson et al. } \\
\text { (2012) [73] }\end{array}$ & 191 & Irish & $\begin{array}{l}28-46 \text { years } \\
64-102 \text { years }\end{array}$ & N/A & N/A & $\begin{array}{l}\text { Microbiota composition clustered by } \\
\text { diet and residence location + significantly } \\
\text { correlated with frailty, co-morbidity, and } \\
\text { inflammation }\end{array}$ \\
\hline $\begin{array}{l}\text { Rampelli et al. } \\
\text { (2013) [71] }\end{array}$ & 9 & Italian & 38-102 years & $\begin{array}{l}\text { Bacterial DNA gene expression for: } \\
\text { short-chain fatty acid production } \\
\text { Proteolytic functions } \\
\text { Pathobionts }\end{array}$ & $\begin{array}{l}\downarrow \\
\uparrow \\
\uparrow\end{array}$ & \\
\hline $\begin{array}{l}\text { Jeffery et al. } \\
\text { (2016) [40] }\end{array}$ & 371 & Irish & $64-102$ years & N/A & N/A & $\begin{array}{l}\text { Longitudinal samples revealed temporal } \\
\text { instability of microbiota } \\
\text { Low microbial diversity associated with } \\
\text { greater temporal instability } \\
\text { Long-term care stays and antibiotic use } \\
\text { associated with increased alterations in } \\
\text { microbial composition and diversity }\end{array}$ \\
\hline $\begin{array}{l}\text { Jackson et al. } \\
\text { (2016) [41] }\end{array}$ & 1008 & $\begin{array}{l}\text { British } \\
\text { Irish }\end{array}$ & $42-102$ years & N/A & N/A & $\begin{array}{l}\text { Robust associations between frailty and } \\
\text { gut microbiota } \\
\text { F. prausnitzii negatively associated } \\
\text { E. dolichum and E. lenta positively } \\
\text { associated }\end{array}$ \\
\hline $\begin{array}{l}\text { Odamaki et al. } \\
\text { (2016) [133] }\end{array}$ & 367 & Japanese & 0-104 years & $\begin{array}{l}\text { Proteobacteria/Bacteroidetes } \\
\text { Firmicutes/Actinobacteria }\end{array}$ & $\begin{array}{l}\downarrow \\
\uparrow\end{array}$ & \\
\hline $\begin{array}{l}\text { Cattaneo et al. } \\
\text { (2017) [42] }\end{array}$ & 83 & Italian & Mean $\sim 70$ years $^{b}$ & N/A & N/A & $\begin{array}{l}\text { Gut microbial populations and } \\
\text { peripheral inflammatory cytokines } \\
\text { associated with cognitive } \\
\text { impairment and brain amyloidosis }\end{array}$ \\
\hline
\end{tabular}

CDAD clostridium difficile-associated diarrhea, ${ }^{\mathrm{a}} \mathrm{Age}$-effect compared to prior study of young adults; $H E$ hospitalized elderly patients on antibotics, ${ }^{\mathrm{b}}$ range and overall mean for the full study not reported (reported by study group)

content were also moderately associated with circulating plasma concentrations of inflammatory cytokines interleukins six (IL-6) and eight (IL-8). Surprisingly, however, despite these interesting findings among the centenarians, this group did not find significant differences in microbiota composition between the younger adults and a group of older adults with an average age of 70 years.

In contrast, findings from the Irish ELDERMET cohort [72] did indicate alterations in the core microbiota of persons over 65 years of age. These changes were generally characterized by a greater proportion of Bacteroides spp. and distinct abundance patterns of Clostridium groups compared to younger individuals. Older individuals also displayed a loss of diversity-associated taxa, including Prevotella and associated genera [40, 73], which can contribute to instability in the microbiome composition. However, the authors noted that the variability in the microbiota profiles of the older persons was 
quite large-making phenotype prediction difficult. Several key factors-particularly diet and the use of antibiotics-were key predictors of these changes in both community-dwelling seniors and residents of long-term care facilities. These factors, diet in particular, could potentially explain differences between findings from the Italian and Irish cohorts. As such, these and other relevant factors necessitate the continued study of the microbiome across populations.

Notably, data from the ELDERMET cohort revealed an interesting potential association with physical frailty as evidenced by differences among older persons living in long-term care and/or rehabilitation facilities compared to community-dwelling peers [73]. These differences were also associated with several systemic markers of inflammation including IL-6, IL8 , CRP, and TNF- $\alpha$. The association with frailty in the cohort was recently demonstrated more formally along with concordant findings from 728 female twins enrolled in the Healthy Ageing Twin Study [41]. These findings were similar to those from a prior small cohort of older adults from The Netherlands [74]. Thus, available data suggest that the gut microbiome may play at least some role in the development of physical frailty among the elderly.

Similarly, early findings now suggest that gut dysbiosis may contribute to age-related declines in cognitive function. Cattaneo et al. recently reported that brain amyloidosis and peripheral inflammation among cognitively impaired elders was associated with the abundance of pro- and anti-inflammatory gut microbiota [42]. Indeed, brain amyloid content and circulating inflammatory analytes were positively associated with the inflammatory bacteria taxon Escherichia/Shigella and negatively associated with the anti-inflammatory E. rectale taxon. To my knowledge, these are the first data directly linking the gut microbiota to age-related cognitive decline, though numerous studies in other models (e.g., Parkinson's, multiple sclerosis, animal models of Alzheimer's disease) exist to indicate a well-defined gut-brain axis which could contribute to age-related dementias [62, 75, 76]. Given the dramatic public health implications of understanding and intervening upon age-related dementias, continued research in this area seems highly warranted.

\section{Etiology of age-related changes in the microbiome}

The precise etiologic explanation for these age-related changes remains incomplete. Across the agespectrum, dramatic increases in the use of antibiotics and increasing pervasiveness of a high-saturated fat and high-sugar "western" diet are proposed to directly contribute to the depletion of important beneficial components of the microbiome [50, 77]. In turn, these changes contribute to chronic activation of the immune system and a dramatic rise in the prevalence of chronic inflammatory disorders. These two factors also represent key modifiable health factors which may contribute to exacerbated dysbiosis among older adults.

In the United States of America, rates of antibiotic prescription actually dropped from 2000-2010 among children and young to middle-aged adults [78]. In contrast, prescription rates increased among older adults with the most dramatic increases seen among persons $\geq 80$ years of age [78]. Additionally, rates of antibiotic prescription have risen substantially in recent years in residential care facilities [79]. These trends may at least partially explain age-related changes in the microbiome, particularly those observed in the ELDERMET cohort among residents of long-term care facilities.

Similarly, age-related changes in nutrient intake may also contribute to late-life dysbiosis. It is wellrecognized that diet is one of the primary contributors to gut health. Advanced age is associated with deterioration in various aspects of nutrient intake and absorption including dentition, salivary function, digestion, and intestinal transit time [73, 80]. Sensory changes, including taste and smell, may also alter the appetite making certain foods unappealing and thus altering eating habits [81]. It is possible that these changes contribute to dysbiosis though it may be more likely that altered immune responses to "inflammatory" foods among older adults may exacerbate microbial changes.

Another prominent possibility is that chronic activation of the innate and adaptive immune systems due to immunosenescence contributes to an altered bacterial composition in the gut. Such an affect may manifest at least partially due to known increases in hypothalamus-pituitary-adrenal (HPA) axis activity in advanced age [82] as HPA-mediated inflammatory stress responses are known to induce to both immune dysregulation [83] and dysbiosis [84]. Conversely, however, it remains possible-given the known inflammatory effects of dysbiosis-that changes to the microbiome due to other factors (e.g., diet) exacerbate inflammation and altered immunity. Thus, it is presently difficult to decipher the temporal relationship between these changes. Furthermore, this known interplay suggests a tantalizing hypothesis that the processes of immunosenescence and dysbiosis may in fact be interdependent. 
Moreover, physical changes to the intestinal epithelial barrier may play a role in dysbiosis and agerelated inflammation. Jakobsson et al. previously demonstrated that the composition of the gut microbiota is directly related to the leaky gut [85]. Recent evidence suggests now that intestinal permeability may increase with age. Man et al. [86] recently demonstrated that, compared to younger adults, ileal tissues from older adults demonstrated increased IL-6 concentrations that were accompanied by increased intestinal permeability as a result of elevated claudin-2. These data provide novel evidence from humans indicating the likelihood of a "leaky gut" during advanced age whereby the intestinal barrier preventing harmful substances from reaching the bloodstream is permeated. The leaky gut is well-associated with inflammatory bowel conditions but is now being proposed as a contributor to a wide variety of health conditions $[87,88]$-with particular interest in a gut-brain axis which regulates the blood brain barrier [61, 62, 75, 76].

Though somewhat speculative at present, it is possible that the leaky gut is a primary source of inflammation long-observed within the circulation. Studies in Drosophila have reported that age-related changes in the microbiome increase intestinal permeability [89] and drive chronic inflammation [90]. More recently, Thevaranjan et al. [91] were the first to our knowledge to publish work from mammals directly supporting this hypothesis. Using germ-free and conventionally raised mice, this group reported that the germ-free animals did not display an age-related increase in systemic pro-inflammatory cytokines. Moreover, co-housing germ-free with old-but not young-conventionally raised mice increased circulating pro-inflammatory cytokines [91]. Anti-TNF therapy also reversed age-related microbial changes. These data are the strongest to date suggesting the critical role of gut changes in driving age-related inflammation and provide a solid backdrop for continued investigation in this area.

\section{Potential intervention strategies}

Though additional research is certainly needed in this area, the aforementioned data do suggest that interventions designed to target the gut microbiome may be capable of producing beneficial effects on age-related inflammation and overall health. To date, research on such interventions is as limited as that on the aging microbiome in general. Still, within this small evidence base are some intriguing and promising findings that support the concept of intervening upon the microbiome.

Interestingly, some of the most promising strategies are not truly "gut-specific" but rather well-known interventions which are increasingly recognized to have beneficial effects on the gut microbiome. For instance, dietary habits appear to be one of the biggest drivers of gut health and microbiota composition [92-94]. Specifically, adherence to a high-fat diet commonly seen in Western cultures appears to be one of the driving factors in gut dysbiosis [95, 96]. Accordingly, interventions such as caloric restriction and/or implementing a Mediterranean-style diet may hold promise for balancing the gut microbiome [97, 98]. Moreover, studies exist to suggest potential benefits to specific dietary choices and/or nutritional supplements including (but not necessarily limited to) coffee [99], resveratrol [100], quercetin [100], and/or other polyphenol compounds [101]. Interestingly, many of these strategies have previously been purported to have anti-inflammatory and/or healthy aging properties. These new data suggest that perhaps influences at the level of the gut may be at least partially responsible for these purported benefits. However, studies are needed that specifically evaluate the influence of dietary changes on the gut microbiome and other health parameters among older adults.

Similarly, physical exercise is a clinically recommended intervention with well-established health benefits which is now purported to have important benefits on the gut [102-105]. Recent studies in laboratory animals have demonstrated that aerobic exercise provides a variety of beneficial effects on the gut including enhancing epithelial membrane integrity [106], increasing microbial diversity [106-109], and attenuating intestinal inflammation $[106,110,111]$. However, few human studies in this area have been published to date. Recently, Clarke et al. [112] recently reported that professional athletes (rugby players) displayed a higher diversity of gut microorganisms compared to age-matched controls. However, extensive additional findings from human$s$-particularly in the form of longitudinal intervention studies-are needed to confirm these beneficial effects. Moreover, to my knowledge, no studies (human or animal) have evaluated the influence of exercise on the gut microbiome in late life. Additionally, questions remain regarding the effects of exercise modality and if these observed effects are specific to aerobic exercise compared to resistance training.

Perhaps not surprisingly, dietary supplementation with probiotics also appears to be among the most promising interventions for re-balancing the gut microbiome. Well-known actions of probiotics include antimicrobial activity, enhancement of intestinal barrier function, and immunomodulation via actions on a wide variety of immune cells [113]. In line with these established mechanisms, studies among older 
adults have demonstrated beneficial effects of probiotic preparations on gut microflora composition [114-116] and systemic immunity [116-118]. van Beek et al. also recently reported that 10 weeks of supplementation with the probiotic Lactobacillus plantarum WCFS1 prevented age-related decline in the colon mucus barrier in a mouse model of accelerated aging [119]. Probiotics have also been proposed to potentially have anti-inflammatory properties [113]. Such an effect seems plausible given the effects of probiotics on the immune system. To date, several studies have investigated this potential antiinflammatory affect with the overall effect appearing to be modest [116, 118-122] - though more definitive research in this area is certainly warranted.

More research is also needed regarding the ability to utilize probiotics as a vehicle to deliver other therapeutic compounds. Indeed, genetically modified probiotics have been purported as highly promising treatment strategies [123-125] as they offer a potentially efficacious method to deliver drugs or other therapeutic proteins with precision and a higher degree of site specificity than conventional drug regimens [126]. For instance, Steidler et al. previously reported on the utility of Lactococcus lactis as a vehicle for delivering IL-10 for the treatment of inflammatory bowel disease [127]. Elsewhere this strategy has been proposed as a potential method of delivering antihypertensive therapeutics [128, 129]. Given the relative infancy of this field, however, the overall body of literature in this area is sparse.
Future studies are certainly warranted on the potential utility of genetically modified probiotics in the treatment of age-related inflammation and associated diseases.

\section{Conclusions}

As the population ages across developed nations worldwide, the need for healthcare solutions to ease the burden of age-related diseases grows. Treatments for chronic inflammation represent a particularly promising strategy given the observation of inflammation in "healthy aging" as well as nearly every age-related disorder or disease. Growing evidence indicates that the gut microbiome may represent a novel site of intervention for the prevention and/or treatment of late-life inflammation. A variety of biologic, medical, and lifestyle factors appear to contribute to gut dysbiosis in late-life, and interventions specifically designed to target these factors may be useful in restoring microbial balance and attenuating inflammation (Fig. 3). Still, much remains to be unraveled as it relates to the influence of the gut microbiome on age-related inflammation-particularly as it relates to the potential efficacy of gutdirected interventions. Thus, this field appears to offer great opportunities for aging-related research. I look forward to continued investigation in this area as it has the potential to yield tremendous breakthroughs for improving the health and quality of life of older persons.

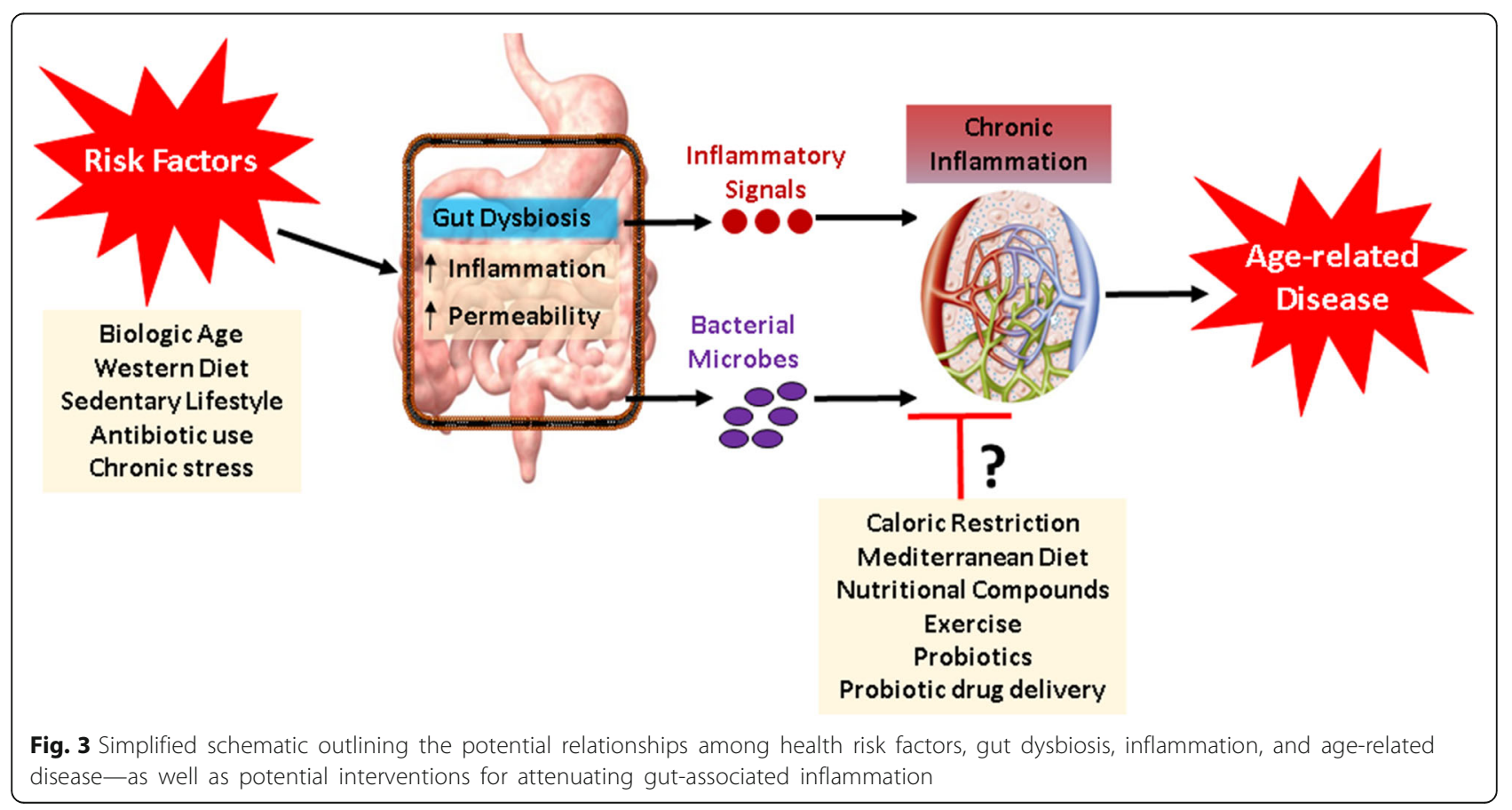




\section{Abbreviations}

CRP: C-reactive protein; HPA: Hypothalamus-pituitary-adrenal; IL-6: Interleukin 6; IL-8: Interleukin 8; SCFA: Short-chain fatty acids; TLR: Toll-like receptor; TNF-a: Tumor necrosis factor alpha

\section{Acknowledgments}

None

\section{Funding}

No funding was necessary to complete the present review.

\section{Availability of data and materials}

Data sharing not applicable to this article as no datasets were generated or analyzed during the current study.

\section{Author contributions}

Dr. Buford is responsible for all aspects of the article.

\section{Ethics approval and consent to participate}

Not applicable

\section{Consent for publication}

Not applicable

\section{Competing Interests}

The author declares that there are no competing interests associated with this manuscript.

\section{Publisher's Note}

Springer Nature remains neutral with regard to jurisdictional claims in published maps and institutional affiliations.

Received: 9 May 2017 Accepted: 4 July 2017

Published online: 14 July 2017

\section{References}

1. Franceschi C, Motta L, Motta M, Malaguarnera M, Capri M, Vasto S, Candore G, Caruso C, IMUSCE. The extreme longevity: the state of the art in Italy. Exp Gerontol. 2008;43(2):45-52

2. Troen BR. The biology of aging. Mt Sinai J Med. 2003;70(1):3-22

3. Candore G, Colonna-Romano G, Balistreri CR, Di Carlo D, Grimaldi MP, Listi F, Nuzzo D, Vasto S, Lio D, Caruso C. Biology of longevity: role of the innate immune system. Rejuvenation Res. 2006;9(1):143-8.

4. Buford TW. Hypertension and aging. Ageing Res Rev. 2016;26:96-111.

5. Cevenini E, Caruso C, Candore G, Capri M, Nuzzo D, Duro G, Rizzo C, Colonna-Romano G, Lio D, Di Carlo D, Palmas MG, Scurti M, Pini E, Franceschi C, Vasto S. Age-related inflammation: the contribution of different organs, tissues and systems. How to face it for therapeutic approaches. Curr Pharm Des. 2010;16(6):609-18.

6. Chung HY, Cesari M, Anton S, Marzetti E, Giovannini S, Seo AY, Carter C, Yu BP, Leeuwenburgh C. Molecular inflammation: underpinnings of aging and age-related diseases. Ageing Res Rev. 2009;8(1):18-30.

7. Singh $T$, Newman $A B$. Inflammatory markers in population studies of aging Ageing Res Rev. 2011;10(3):319-29.

8. Vasto $\mathrm{S}$, Candore G, Balistreri CR, Caruso M, Colonna-Romano G, Grimaldi MP, Listi F, Nuzzo D, Lio D, Caruso C. Inflammatory networks in ageing, age-related diseases and longevity. Mech Ageing Dev. 2007; 128(1):83-91.

9. Sarkar D, Fisher PB. Molecular mechanisms of aging-associated inflammation. Cancer Lett. 2006;236(1):13-23.

10. Wei J, Xu H, Davies JL, Hemmings GP. Increase of plasma IL-6 concentration with age in healthy subjects. Life Sci. 1992;51(25):1953-6.

11. Ershler WB, Sun WH, Binkley N, Gravenstein S, Volk MJ, Kamoske G, Klopp RG, Roecker EB, Daynes RA, Weindruch R. Interleukin-6 and aging: blood levels and mononuclear cell production increase with advancing age and in vitro production is modifiable by dietary restriction. Lymphokine Cytokine Res. 1993:12(4):225-30.

12. Fagiolo U, Cossarizza A, Scala E, Fanales-Belasio E, Ortolani C, Cozzi E, Monti D. Franceschi C, Paganelli R. Increased cytokine production in mononuclear cells of healthy elderly people. Eur J Immunol. 1993;23(9):2375-8.
13. Tracy RP, Lemaitre RN, Psaty BM, Ives DG, Evans RW, Cushman M, Meilahn EN, Kuller LH. Relationship of C-reactive protein to risk of cardiovascular disease in the elderly. Results from the Cardiovascular Health Study and the Rural Health Promotion Project. Arterioscler Thromb Vasc Biol. 1997;17(6): $1121-7$.

14. Cesari M, Penninx BW, Newman AB, Kritchevsky SB, Nicklas BJ, Sutton-Tyrrell K, Tracy RP, Rubin SM, Harris TB, Pahor M. Inflammatory markers and cardiovascular disease (The Health, Aging and Body Composition [Health ABC] Study). Am J Cardiol. 2003:92(5):522-8.

15. Cesari M, Penninx BW, Newman AB, Kritchevsky SB, Nicklas BJ, Sutton-Tyrrell K, Rubin SM, Ding J, Simonsick EM, Harris TB, Pahor M. Inflammatory markers and onset of cardiovascular events: results from the Health $A B C$ study. Circulation. 2003:108(19):2317-22.

16. Pickup JC, Chusney GD, Thomas SM, Burt D. Plasma interleukin-6, tumour necrosis factor alpha and blood cytokine production in type 2 diabetes. Life Sci. 2000;67(3):291-300.

17. Pradhan AD, Manson JE, Rifai N, Buring JE, Ridker PM. C-reactive protein, interleukin 6, and risk of developing type 2 diabetes mellitus. JAMA. 2001; 286(3):327-34.

18. Bertoni AG, Burke GL, Owusu JA, Carnethon MR, Vaidya D, Barr RG, Jenny NS, Ouyang P, Rotter II. Inflammation and the incidence of type 2 diabetes: the Multi-Ethnic Study of Atherosclerosis (MESA). Diabetes Care. 2010;33(4): 804-10.

19. Khosla S, Peterson JM, Egan K, Jones JD, Riggs BL. Circulating cytokine levels in osteoporotic and normal women. J Clin Endocrinol Metab. 1994;79(3): $707-11$.

20. Zheng SX, Vrindts $Y$, Lopez $M$, De Groote D, Zangerle PF, Collette J, Franchimont N, Geenen V, Albert A, Reginster JY. Increase in cytokine production (IL-1 beta, IL-6, TNF-alpha but not IFN-gamma, GM-CSF or LIF) by stimulated whole blood cells in postmenopausal osteoporosis. Maturitas. 1997;26(1):63-71.

21. Ding C, Parameswaran V, Udayan R, Burgess J, Jones G. Circulating levels of inflammatory markers predict change in bone mineral density and resorption in older adults: a longitudinal study. J Clin Endocrinol Metab. 2008;93(5):1952-8

22. Yaffe K, Lindquist K, Penninx BW, Simonsick EM, Pahor M, Kritchevsky S, Launer L, Kuller L, Rubin S, Harris T. Inflammatory markers and cognition in well-functioning African-American and white elders. Neurology. 2003;61(1): $76-80$.

23. Weaver JD, Huang MH, Albert M, Harris T, Rowe JW, Seeman TE. Interleukin6 and risk of cognitive decline: MacArthur studies of successful aging. Neurology. 2002:59(3):371-8

24. Engelhart MJ, Geerlings MI, Meijer J, Kiliaan A, Ruitenberg A, van Swieten JC, Stijnen T, Hofman A, Witteman JC, Breteler MM. Inflammatory proteins in plasma and the risk of dementia: the rotterdam study. Arch Neurol. 2004; 61(5):668-72.

25. Ershler WB, Keller ET. Age-associated increased interleukin-6 gene expression, late-life diseases, and frailty. Annu Rev Med. 2000;51: 245-70.

26. Walston J, McBurnie MA, Newman A, Tracy RP, Kop WJ, Hirsch CH, Gottdiener J, Fried LP, Cardiovascular Health Study. Frailty and activation of the inflammation and coagulation systems with and without clinical comorbidities: results from the Cardiovascular Health Study. Arch Intern Med. 2002;162(20):2333-41.

27. Ferrucci L, Penninx BW, Volpato S, Harris TB, Bandeen-Roche K, Balfour J, Leveille SG, Fried LP, Md JM. Change in muscle strength explains accelerated decline of physical function in older women with high interleukin-6 serum levels. J Am Geriatr Soc. 2002;50(12): 1947-54.

28. Aggarwal BB, Shishodia S, Sandur SK, Pandey MK, Sethi G. Inflammation and cancer: how hot is the link? Biochem Pharmacol. 2006;72(11):1605-21.

29. Lu H, Ouyang W, Huang C. Inflammation, a key event in cancer development. Mol Cancer Res. 2006;4(4):221-33.

30. II'yasova D, Colbert LH, Harris TB, Newman AB, Bauer DC, Satterfield S, Kritchevsky SB. Circulating levels of inflammatory markers and cancer risk in the health aging and body composition cohort. Cancer Epidemiol Biomarkers Prev. 2005;14(10):2413-8.

31. Newman AB, Sachs MC, Arnold AM, Fried LP, Kronmal R, Cushman M, Psaty BM, Harris TB, Robbins JA, Burke GL, Kuller LH, Lumley T. Total and causespecific mortality in the cardiovascular health study. J Gerontol A Biol Sci Med Sci. 2009;64(12):1251-61. 
32. Harris TB, Ferrucci L, Tracy RP, Corti MC, Wacholder S, Ettinger Jr WH, Heimovitz H, Cohen HJ, Wallace R. Associations of elevated interleukin-6 and C-reactive protein levels with mortality in the elderly. Am J Med. 1999; 106(5):506-12.

33. Roubenoff $R$, Parise $H$, Payette HA, Abad LW, D'Agostino R, Jacques PF, Wilson PW, Dinarello CA, Harris TB. Cytokines, insulin-like growth factor 1, sarcopenia, and mortality in very old community-dwelling men and women: the Framingham Heart Study. Am J Med. 2003; 115(6):429-35.

34. Krabbe KS, Pedersen $M$, Bruunsgaard $H$. Inflammatory mediators in the elderly. Exp Gerontol. 2004;39(5):687-99.

35. Phillips AC, Burns VE, Lord JM. Stress and exercise: getting the balance right for aging immunity. Exerc Sport Sci Rev. 2007;35(1):35-9.

36. Hawkley LC, Cacioppo JT. Stress and the aging immune system. Brain Behav Immun. 2004:18(2):114-9.

37. De Martinis M, Franceschi C, Monti D, Ginaldi L. Apoptosis remodeling in immunosenescence: implications for strategies to delay ageing. Curr Med Chem. 2007;14(13):1389-97.

38. Buford TW, Willoughby DS. Impact of DHEA(S) and cortisol on immune function in aging: a brief review. Appl Physiol Nutr Metab. 2008;33(3): 429-33.

39. Wick G, Berger P, Jansen-Durr P, Grubeck-Loebenstein B. A Darwinianevolutionary concept of age-related diseases. Exp Gerontol. 2003;38(1-2): $13-25$.

40. Jeffery IB, Lynch DB, O'Toole PW. Composition and temporal stability of the gut microbiota in older persons. ISME J. 2016;10(1):170-82.

41. Jackson MA, Jeffery IB, Beaumont M, Bell JT, Clark AG, Ley RE, O'Toole PW, Spector TD, Steves CJ. Signatures of early frailty in the gut microbiota. Genome Med. 2016;8(1):8. -016-0262-7.

42. Cattaneo A, Cattane N, Galluzzi S, Provasi S, Lopizzo N, Festari C, Ferrari C, Guerra UP, Paghera B, Muscio C, Bianchetti A, Volta GD, Turla M, Cotelli MS, Gennuso M, Prelle A, Zanetti O, Lussignoli G, Mirabile D, Bellandi D, Gentile S, Belotti G, Villani D, Harach T, Bolmont T, Padovani A, Boccardi M, Frisoni GB, INDIA-FBP Group. Association of brain amyloidosis with pro-inflammatory gut bacterial taxa and peripheral inflammation markers in cognitively impaired elderly. Neurobiol Aging. 2017:49:60-8.

43. Gill SR, Pop M, Deboy RT, Eckburg PB, Turnbaugh PJ, Samuel BS, Gordon J, Relman DA, Fraser-Liggett CM, Nelson KE. Metagenomic analysis of the human distal gut microbiome. Science. 2006;312(5778):1355-9.

44. Ley RE, Peterson DA, Gordon J. Ecological and evolutionary forces shaping microbial diversity in the human intestine. Cell. 2006;124(4):837-48.

45. Cox LM, Blaser MJ. Antibiotics in early life and obesity. Nat Rev Endocrinol. 2015;11(3):182-90.

46. O'Hara AM, Shanahan F. The gut flora as a forgotten organ. EMBO Rep. 2006;7(7):688-93.

47. Egert M, de Graaf AA, Smidt H, de Vos WM, Venema K. Beyond diversity: functional microbiomics of the human colon. Trends Microbiol. 2006;14(2): 86-91.

48. Thaiss CA, Zeevi D, Levy M, Zilberman-Schapira G, Suez J, Tengeler AC, Abramson L, Katz MN, Korem T, Zmora N, Kuperman Y, Biton I, Gilad S, Harmelin A, Shapiro H, Halpern Z, Segal E, Elinav E. Transkingdom control of microbiota diurnal oscillations promotes metabolic homeostasis. Cell. 2014; 159(3):514-29.

49. Collins SM, Surette M, Bercik P. The interplay between the intestinal microbiota and the brain. Nat Rev Microbiol. 2012;10(11):735-42.

50. Belkaid $Y$, Hand TW. Role of the microbiota in immunity and inflammation Cell. 2014;157(1):121-41.

51. Rakoff-Nahoum S, Paglino J, Eslami-Varzaneh F, Edberg S, Medzhitov R Recognition of commensal microflora by toll-like receptors is required for intestinal homeostasis. Cell. 2004;118(2):229-41.

52. Maslowski KM, Vieira AT, Ng A, Kranich J, Sierro F, Yu D, Schilter HC, Rolph MS, Mackay F, Artis D, Xavier RJ, Teixeira MM, Mackay CR. Regulation of inflammatory responses by gut microbiota and chemoattractant receptor GPR43. Nature. 2009;461(7268):1282-6.

53. Belkaid $Y$, Naik S. Compartmentalized and systemic control of tissue immunity by commensals. Nat Immunol. 2013;14(7):646-53.

54. Abt MC, Osborne LC, Monticelli LA, Doering TA, Alenghat T, Sonnenberg GF, Paley MA, Antenus M, Williams KL, Erikson J, Wherry EJ, Artis D. Commensal bacteria calibrate the activation threshold of innate antiviral immunity. Immunity. 2012;37(1):158-70.
55. Hill DA, Siracusa MC, Abt MC, Kim BS, Kobuley D, Kubo M, Kambayashi T, Larosa DF, Renner ED, Orange JS, Bushman FD, Artis D. Commensal bacteria-derived signals regulate basophil hematopoiesis and allergic inflammation. Nat Med. 2012;18(4):538-46.

56. Ichinohe T, Pang IK, Kumamoto Y, Peaper DR, Ho JH, Murray TS, Iwasaki A. Microbiota regulates immune defense against respiratory tract influenza A virus infection. Proc Natl Acad Sci U S A. 2011;108(13):5354-9.

57. Bruzzese E, Callegari ML, Raia V, Viscovo S, Scotto R, Ferrari S, Morelli L, Buccigrossi V, Lo Vecchio A, Ruberto E, Guarino A. Disrupted intestinal microbiota and intestinal inflammation in children with cystic fibrosis and its restoration with Lactobacillus GG: a randomised clinical trial. PLoS One. 2014;9(2):e87796.

58. Frank DN, St Amand AL, Feldman RA, Boedeker EC, Harpaz N, Pace NR. Molecular-phylogenetic characterization of microbial community imbalances in human inflammatory bowel diseases. Proc Natl Acad Sci U S A. 2007;104(34):13780-5

59. Dubinsky MC, Lin YC, Dutridge D, Picornell $Y$, Landers CJ, Farrior S, Wrobel I, Quiros A, Vasiliauskas EA, Grill B, Israel D, Bahar R, Christie D, Wahbeh G, Silber G, Dallazadeh S, Shah P, Thomas D, Kelts D, Hershberg RM, Elson CO, Targan SR, Taylor KD, Rotter Jl, Yang H, Western Regional Pediatric IBD Research Alliance. Serum immune responses predict rapid disease progression among children with Crohn's disease: immune responses predict disease progression. Am J Gastroenterol. 2006;101(2):360-7.

60. O'Keefe SJ, Ou J, Aufreiter S, O'Connor D, Sharma S, Sepulveda J, Fukuwatari T, Shibata K, Mawhinney T. Products of the colonic microbiota mediate the effects of diet on colon cancer risk. J Nutr. 2009:139(11):2044-8.

61. Sampson TR, Debelius JW, Thron T, Janssen S, Shastri GG, Ithan ZE, Challis C, Schretter CE, Rocha S, Gradinaru V, Chesselet MF, Keshavarzian A, Shannon KM, Krajmalnik-Brown R, Wittung-Stafshede P, Knight R, Mazmanian SK. Gut Microbiota Regulate Motor Deficits and Neuroinflammation in a Model of Parkinson's Disease. Cell. 2016;167(6):1469-1480.e12.

62. Hu X, Wang T, Jin F. Alzheimer's disease and gut microbiota. Sci China Life Sci. 2016;59(10):1006-23.

63. Berer K, Mues M, Koutrolos M, Rasbi ZA, Boziki M, Johner C, Wekerle $H$, Krishnamoorthy G. Commensal microbiota and myelin autoantigen cooperate to trigger autoimmune demyelination. Nature. 2011;479(7374): 538-41.

64. Barlow GM, Yu A, Mathur R. Role of the gut microbiome in obesity and diabetes mellitus. Nutr Clin Pract. 2015:30(6):787-97.

65. Komaroff AL. The Microbiome and Risk for Obesity and Diabetes. JAMA. 2017:317(4):355-6

66. Britton RA, Irwin R, Quach D, Schaefer L, Zhang J, Lee T, Parameswaran N, McCabe LR. Probiotic L. reuteri treatment prevents bone loss in a menopausal ovariectomized mouse model. J Cell Physiol. 2014;229(11): 1822-30.

67. Scher JU, Sczesnak A, Longman RS, Segata N, Ubeda C, Bielski C, Rostron T, Cerundolo V, Pamer EG, Abramson SB, Huttenhower C, Littman DR. Expansion of intestinal Prevotella copri correlates with enhanced susceptibility to arthritis. Elife. 2013;2:e01202.

68. Vieira AT, Macia L, Galvao I, Martins FS, Canesso MC, Amaral FA, Garcia CC, Maslowski KM, De Leon E, Shim D, Nicoli JR, Harper JL, Teixeira MM, Mackay CR. A role for gut microbiota and the metabolite-sensing receptor GPR43 in a murine model of gout. Arthritis Rheumatol. 2015; 67(6):1646-56.

69. O'Toole PW, Jeffery IB. Gut microbiota and aging. Science. 2015;350(6265): 1214-5.

70. Biagi E, Nylund L, Candela M, Ostan R, Bucci L, Pini E, Nikkila J, Monti D, Satokari R, Franceschi C, Brigidi P, De Vos W. Through ageing, and beyond: gut microbiota and inflammatory status in seniors and centenarians. PLoS One. 2010;5(5):e10667.

71. Rampelli S, Candela M, Turroni S, Biagi E, Collino S, Franceschi C, O'Toole PW, Brigidi P. Functional metagenomic profiling of intestinal microbiome in extreme ageing. Aging (Albany NY). 2013;5(12):902-12.

72. Claesson MJ, Cusack S, O'Sullivan O, Greene-Diniz R, de Weerd H, Flannery E, Marchesi JR, Falush D, Dinan T, Fitzgerald G, Stanton C, van Sinderen D, O'Connor M, Harnedy N, O'Connor K, Henry C, O'Mahony D, Fitzgerald AP, Shanahan F, Twomey C, Hill C, Ross RP, O'Toole PW. Composition, variability, and temporal stability of the intestinal microbiota of the elderly. Proc Natl Acad Sci U S A. 2011;108 Suppl 1:4586-91. 
73. Claesson MJ, Jeffery IB, Conde S, Power SE, O'Connor EM, Cusack S, Harris HM, Coakley M, Lakshminarayanan B, O'Sullivan O, Fitzgerald GF, Deane J, O'Connor M, Harnedy N, O'Connor K, O'Mahony D, van Sinderen D, Wallace M, Brennan L, Stanton C, Marchesi JR, Fitzgerald AP, Shanahan F, Hill C, Ross RP, O'Toole PW. Gut microbiota composition correlates with diet and health in the elderly. Nature. 2012;488(7410):178-84.

74. van Tongeren SP, Slaets JP, Harmsen HJ, Welling GW. Fecal microbiota composition and frailty. Appl Environ Microbiol. 2005;71(10):6438-42.

75. Proctor C, Thiennimitr P, Chattipakorn N, Chattipakorn SC: Diet, gut microbiota and cognition. Metab Brain Dis. 2017;32(1):1-17.

76. Alkasir R, Li J, Li X, Jin M, Zhu B. Human gut microbiota: the links with dementia development. Protein Cell. 2017:8(2):90-102.

77. Blaser MJ, Falkow S. What are the consequences of the disappearing human microbiota? Nat Rev Microbiol. 2009;7(12):887-94.

78. Lee GC, Reveles KR, Attridge RT, Lawson KA, Mansi IA, Lewis JS,2nd, Frei CR. Outpatient antibiotic prescribing in the United States: 2000 to 2010. BMC Med. 2014;12:96-7015-12-96.

79. Lim CJ, Kong DC, Stuart RL. Reducing inappropriate antibiotic prescribing in the residential care setting: current perspectives. Clin Interv Aging. 2014;9: $165-77$.

80. Lovat LB. Age related changes in gut physiology and nutritional status. Gut. 1996:38(3):306-9.

81. Fukunaga $A$, Uematsu $H$, Sugimoto $K$. Influences of aging on taste perception and oral somatic sensation. J Gerontol A Biol Sci Med Sci. 2005;60(1):109-13.

82. McEwen BS. Protective and damaging effects of stress mediators. N Engl J Med. 1998;338(3):171-9.

83. Bauer ME. Stress, glucocorticoids and ageing of the immune system. Stress. 2005;8(1):69-83.

84. Galley JD, Bailey MT. Impact of stressor exposure on the interplay between commensal microbiota and host inflammation. Gut Microbes. 2014;5(3):390-6.

85. Jakobsson HE, Rodriguez-Pineiro AM, Schutte A, Ermund A, Boysen P, Bemark M, Sommer F, Backhed F, Hansson GC, Johansson ME. The composition of the gut microbiota shapes the colon mucus barrier. EMBO Rep. 2015;16(2):164-77.

86. Man AL, Bertelli E, Rentini S, Regoli M, Briars G, Marini M, Watson AJ, Nicoletti C. Age-associated modifications of intestinal permeability and innate immunity in human small intestine. Clin Sci (Lond). 2015;129(7):51527.

87. Nicoletti C. Age-associated changes of the intestinal epithelial barrier: local and systemic implications. Expert Rev Gastroenterol Hepatol. 2015;9(12): 1467-9.

88. Mabbott NA. A breakdown in communication? Understanding the effects of aging on the human small intestine epithelium. Clin Sci (Lond). 2015;129(7): 529-31.

89. Clark Rl, Salazar A, Yamada R, Fitz-Gibbon S, Morselli M, Alcaraz J, Rana A, Rera M, Pellegrini M, Ja WW, Walker DW. Distinct shifts in microbiota composition during drosophila aging impair intestinal function and drive mortality. Cell Rep. 2015;12(10):1656-67.

90. Rera M, Clark RI, Walker DW. Intestinal barrier dysfunction links metabolic and inflammatory markers of aging to death in Drosophila. Proc Natl Acad Sci U S A. 2012;109(52):21528-33.

91. Thevaranjan N, Puchta A, Schulz C, Naidoo A, Szamosi JC, Verschoor CP, Loukov D, Schenck LP, Jury J, Foley KP, Schertzer JD, Larche MJ, Davidson DJ, Verdu EF, Surette MG, Bowdish DM. Age-Associated Microbial Dysbiosis Promotes Intestinal Permeability, Systemic Inflammation, and Macrophage Dysfunction. Cell Host Microbe. 2017;21(4):455-466.e4.

92. Pallister T, Spector TD. Food: a new form of personalised (gut microbiome) medicine for chronic diseases? J R Soc Med. 2016;109(9):331-6.

93. Chen J, He X, Huang J. Diet effects in gut microbiome and obesity. J Food Sci. 2014;79(4):R442-51.

94. Keenan MJ, Marco ML, Ingram DK, Martin RJ. Improving healthspan via changes in gut microbiota and fermentation. Age (Dordr). 2015;37(5):98. -015-9817-6 Epub 2015 Sep 14

95. Backhed F, Manchester JK, Semenkovich CF, Gordon Jl. Mechanisms underlying the resistance to diet-induced obesity in germ-free mice. Proc Natl Acad Sci U S A. 2007;104(3):979-84.

96. Murphy EA, Velazquez KT, Herbert KM. Influence of high-fat diet on gut microbiota: a driving force for chronic disease risk. Curr Opin Clin Nutr Metab Care. 2015;18(5):515-20.
97. De Filippis F, Pellegrini N, Vannini L, Jeffery IB, La Storia A, Laghi L, Serrazanetti DI, Di Cagno R, Ferrocino I, Lazzi C, Turroni S, Cocolin L, Brigidi P, Neviani E, Gobbetti M, O'Toole PW, Ercolini D. High-level adherence to a Mediterranean diet beneficially impacts the gut microbiota and associated metabolome. metabolome. Gut. 2016;65(11):1812-21.

98. Oh B, Kim JS, Kweon M, Kim BS, Huh IS. Six-week diet correction for body weight reduction and its subsequent changes of gut microbiota: a case report. Clin Nutr Res. 2016;5(2):137-40.

99. Cowan TE, Palmnas MS, Yang J, Bomhof MR, Ardell KL, Reimer RA, Vogel HJ, Shearer J. Chronic coffee consumption in the diet-induced obese rat: impact on gut microbiota and serum metabolomics. J Nutr Biochem. 2014; 25(4):489-95.

100. Etxeberria U, Arias N, Boque N, Macarulla MT, Portillo MP, Martinez JA, Milagro Fl. Reshaping faecal gut microbiota composition by the intake of trans-resveratrol and quercetin in high-fat sucrose diet-fed rats. J Nutr Biochem. 2015;26(6):651-60.

101. Cardona F, Andres-Lacueva C, Tulipani S, Tinahones FJ, Queipo-Ortuno MI. Benefits of polyphenols on gut microbiota and implications in human health. J Nutr Biochem. 2013;24(8):1415-22.

102. Mika A, Fleshner M. Early-life exercise may promote lasting brain and metabolic health through gut bacterial metabolites. Immunol Cell Biol. 2016;94(2):151-7.

103. Cerda B, Perez M, Perez-Santiago JD, Tornero-Aguilera JF, GonzalezSoltero R, Larrosa M. Gut microbiota modification: another piece in the puzzle of the benefits of physical exercise in health? Front Physiol. 2016;7:51.

104. Campbell SC, Wisniewski 2nd PJ. Exercise is a novel promoter of intestinal health and microbial diversity. Exerc Sport Sci Rev. 2017;45(1):41-7.

105. O'Sullivan O, Cronin O, Clarke SF, Murphy EF, Molloy MG, Shanahan F, Cotter PD. Exercise and the microbiota. Gut Microbes. 2015;6(2):131-6.

106. Campbell SC, Wisniewski PJ, Noji M, McGuinness LR, Haggblom MM, Lightfoot SA, Joseph LB, Kerkhof LJ. The effect of diet and exercise on intestinal integrity and microbial diversity in mice. PLoS One. 2016;11(3): e0150502.

107. Allen JM, Berg Miller ME, Pence BD, Whitlock K, Nehra V, Gaskins HR, White BA, Fryer JD, Woods JA. Voluntary and forced exercise differentially alters the gut microbiome in C57BL/6J mice. J Appl Physiol (1985). 2015;118((8): 1059-66.

108. Evans CC, LePard KJ, Kwak JW, Stancukas MC, Laskowski S, Dougherty J, Moulton L, Glawe A, Wang Y, Leone V, Antonopoulos DA, Smith D, Chang EB, Ciancio MJ. Exercise prevents weight gain and alters the gut microbiota in a mouse model of high fat diet-induced obesity. PLoS One. 2014;9(3): e92193.

109. Mika A, Van Treuren W, Gonzalez A, Herrera JJ, Knight R, Fleshner M. Exercise is more effective at altering gut microbial composition and producing stable changes in lean mass in juvenile versus adult male F344 Rats. PLoS One. 2015;10(5):e0125889.

110. Hoffman-Goetz L, Pervaiz N, Packer N, Guan J. Freewheel training decreases pro- and increases anti-inflammatory cytokine expression in mouse intestinal lymphocytes. Brain Behav Immun. 2010;24(7):1105-15.

111. Hoffman-Goetz L, Pervaiz N, Guan J. Voluntary exercise training in mice increases the expression of antioxidant enzymes and decreases the expression of TNF-alpha in intestinal lymphocytes. Brain Behav Immun. 2009;23(4):498-506.

112. Clarke SF, Murphy EF, O'Sullivan O, Lucey AJ, Humphreys M, Hogan A, Hayes P, O'Reilly M, Jeffery IB, Wood-Martin R, Kerins DM, Quigley E, Ross RP, O'Toole PW, Molloy MG, Falvey E, Shanahan F, Cotter PD. Exercise and associated dietary extremes impact on gut microbial diversity. Gut. 2014; 63(12):1913-20.

113. Ng SC, Hart AL, Kamm MA, Stagg AJ, Knight SC. Mechanisms of action of probiotics: recent advances. Inflamm Bowel Dis. 2009;15(2):300-10.

114. Ahmed M, Prasad J, Gill H, Stevenson L, Gopal P. Impact of consumption of different levels of Bifidobacterium lactis HN019 on the intestinal microflora of elderly human subjects. J Nutr Health Aging. 2007;11(1):26-31.

115. Rampelli S, Candela M, Severgnini M, Biagi E, Turroni S, Roselli M, Carnevali $P$, Donini L, Brigidi P. A probiotics-containing biscuit modulates the intestinal microbiota in the elderly. J Nutr Health Aging. 2013;17(2):166-72.

116. Liu Y, Gibson GR, Walton GE. An in vitro approach to study effects of prebiotics and probiotics on the faecal microbiota and selected immune parameters relevant to the elderly. PLoS One. 2016;11(9):e0162604. 
117. Gill HS, Rutherfurd KJ, Cross ML, Gopal PK. Enhancement of immunity in the elderly by dietary supplementation with the probiotic Bifidobacterium lactis HN019. Am J Clin Nutr. 2001;74(6):833-9.

118. Moro-Garcia MA, Alonso-Arias R, Baltadjieva M, Fernandez Benitez C, Fernandez Barrial MA, Diaz Ruisanchez E, Alonso Santos R, Alvarez Sanchez M, Saavedra Mijan J, Lopez-Larrea C. Oral supplementation with Lactobacillus delbrueckii subsp. bulgaricus 8481 enhances systemic immunity in elderly subjects. Age (Dordr). 2013;35(4):1311-26.

119. van Beek AA, Sovran B, Hugenholtz F, Meijer B, Hoogerland JA, Mihailova V, van der Ploeg C, Belzer C, Boekschoten MV, Hoeijmakers JH, Vermeij WP, de Vos P, Wells JM, Leenen PJ, Nicoletti C, Hendriks RW, Savelkoul HF. Supplementation with Lactobacillus plantarum WCFS1 Prevents Decline of Mucus Barrier in Colon of Accelerated Aging Ercc1-/Delta7 Mice. Front Immunol. 2016;7:408.

120. Valentini L, Pinto A, Bourdel-Marchasson I, Ostan R, Brigidi P, Turroni S, Hrelia S, Hrelia P, Bereswill S, Fischer A, Leoncini E, Malaguti M, Blanc-Bisson C, Durrieu J, Spazzafumo L, Buccolini F, Pryen F, Donini LM, Franceschi C, Lochs $\mathrm{H}$. Impact of personalized diet and probiotic supplementation on inflammation, nutritional parameters and intestinal microbiota-The "RISTOMED project": randomized controlled trial in healthy older people. Clin Nutr. 2015;34(4):593-602.

121. Ostan R, Bene MC, Spazzafumo L, Pinto A, Donini LM, Pryen F, Charrouf Z, Valentini L, Lochs H, Bourdel-Marchasson I, Blanc-Bisson C, Buccolini F, Brigidi P, Franceschi C, d'Alessio PA. Impact of diet and nutraceutical supplementation on inflammation in elderly people. Results from the RISTOMED study, an open-label randomized control trial. Clin Nutr. 2016; 35(4):812-8

122. Akbari E, Asemi Z, Daneshvar Kakhaki R, Bahmani F, Kouchaki E, Tamtaji OR, Hamidi GA, Salami M. Effect of probiotic supplementation on cognitive function and metabolic status in Alzheimer's disease: a randomized, doubleblind and controlled trial. Front Aging Neurosci. 2016;8:256.

123. Steidler L. Genetically engineered probiotics. Best Pract Res Clin Gastroenterol. 2003;17(5):861-76.

124. Syvanen M. Churning out safer microbes for drug delivery. Nat Biotechnol. 2003;21(7):758-9.

125. Paton AW, Morona R, Paton JC. Bioengineered microbes in disease therapy. Trends Mol Med. 2012;18(7):417-25.

126. Kumar M, Yadav AK, Verma V, Singh B, Mal G, Nagpal R, Hemalatha R. Bioengineered probiotics as a new hope for health and diseases: an overview of potential and prospects. Future Microbiol. 2016;11(4):585-600.

127. Steidler L, Neirynck S, Huyghebaert N, Snoeck V, Vermeire A, Goddeeris B, Cox E, Remon JP, Remaut E. Biological containment of genetically modified Lactococcus lactis for intestinal delivery of human interleukin 10. Nat Biotechnol. 2003;21(7):785-9.

128. Daliri EB, Lee BH, Oh DH. Current Perspectives on Antihypertensive Probiotics. Probiotics Antimicrob Proteins. 2016.

129. Yang G, Jiang Y, Yang W, Du F, Yao Y, Shi C, Wang C. Effective treatment of hypertension by recombinant Lactobacillus plantarum expressing angiotensin converting enzyme inhibitory peptide. Microb Cell Fact. 2015; 14:202-015-0394-2.

130. Hopkins MJ, Macfarlane GT. Changes in predominant bacterial populations in human faeces with age and with Clostridium difficile infection. J Med Microbiol. 2002;51(5):448-54.

131. Hayashi H, Sakamoto M, Kitahara M, Benno Y. Molecular analysis of fecal microbiota in elderly individuals using $16 \mathrm{~S}$ rDNA library and T-RFLP. Microbiol Immunol. 2003;47(8):557-70.

132. Woodmansey EJ, McMurdo ME, Macfarlane GT, Macfarlane S. Comparison of compositions and metabolic activities of fecal microbiotas in young adults and in antibiotic-treated and non-antibiotic-treated elderly subjects. Appl Environ Microbiol. 2004;70(10):6113-22.

133. Odamaki T, Kato K, Sugahara H, Hashikura N, Takahashi S, Xiao JZ, Abe F, Osawa R. Age-related changes in gut microbiota composition from newborn to centenarian: a cross-sectional study. BMC Microbiol. 2016; 16:90-016-0708-5.

\section{Submit your next manuscript to BioMed Central and we will help you at every step:}

- We accept pre-submission inquiries

- Our selector tool helps you to find the most relevant journal

- We provide round the clock customer support

- Convenient online submission

- Thorough peer review

- Inclusion in PubMed and all major indexing services

- Maximum visibility for your research

Submit your manuscript at www.biomedcentral.com/submit 